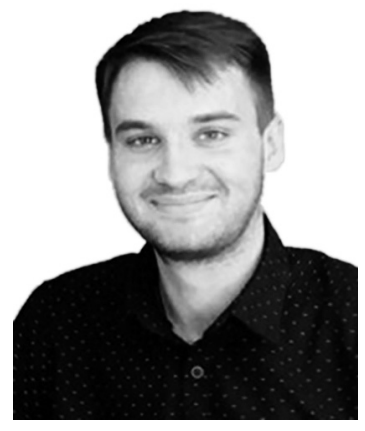

\title{
ANALYSIS OF THE INTERNATIONAL LEGISLATION ON THE COPYRIGHT PROTECTION
}

\author{
LISOVYI Artem - General specialist, the department of considering claims of \\ citizens and providing of public information of the secretariat of the Civil cassation \\ court as a part of Supreme Court Kyiv, Ukraine
}

DOI:10.32782/NP.2020.2.25

One of the most remarkable international act in the history of copyright protection - Berne Convention for the Protection of Literary and Artistic Works, adopted in 1886 in Bern, Switzerland (further - Convention №1), - can rightly be considered as the first international convention aimed to enchance ensuring the author's rights and protection of works of art. Convention №1 provides creators (such as authors, poets, musicians, painters etc.) with the means to control how, by whom and on what terms their works are used.

Notably, the initiator of this Convention was French writer Victor Hugo. During his time of being president of the "Association littéraire et artistique internationale" (ALAI), he was promoting interaction between countries and campaigning for the creation and adoption of international treaty which was intended to protect intellectual property in the arts.

Convetion № 1 has been amended a number of times and its last changes has been enacted in 1979. It has been administered by the United International Bureaux for the Protection of Intellectual Property (BIRPI) from 1893 to 1969 , and thereafter, in 1970 has been overseen by the World Intellectual Property Organization and has fallen under the authority of the United Nations as other important conventions.

This Convention is based on three essential principles, such as: 1) national treatment - principle states that every signatory state agrees to give the similar protection to foreign works as to the works originating in their own country. A foreign work is considered to be any work published for the first time in another country or whose author is from another country. For example, since Ukraine has ratified the Berne Convention, works originating from other signatory states such as Liberia, Switzerland, France, Belgium etc., must be given the same protection as Ukrainian works under the Constitution of Ukraine, the Book IV of the Civil Code of Ukraine and Law of Ukraine «On copyright and related rights»; 2) automatic protection - works are automatically copyrighted as soon as they are "fixed in any material form». More specifically, the protection set out in the signatory states' legislation does not need any formalities and notifications. It's not required to register your work, add your name to it or entail a copyright notice such as (C) symbol in order for the work to be protected by copyright; 3) independence of protection - when used in other countries, works are not limited to the copyright legislation in effect in their country of origin. In other words, all works always protected by the legislation in the country where they are being used. As a result, the protection applied to the particular work varies depending on the territory where it's used, independently of the author's origin or the state in which it was published for the first time ${ }^{1}$.

Besides that, Convention 1 requires the minimum standards to respect from the signa-

1 Copibec, copyright specialists, DO YOU KNOW WHAT THE BERNE CONVENTION IS. https://www. copibec.ca/en/nouvelle/163/savez-vous-ce-qu-est-laconvention-de-berne- (Canada, April 4, 2018) 
tory states. Those standards imply the patrimonial rights, moral rights and minimum duration of copyright for a period of 50 years.

This convention sets, for the first time, the list of literary works and artistic works which are protected internationally and separately by each country. Namely, in the article 1 of it is stated, that 'the countries to which this Convention applies constitute a union for the protection of the rights of authors in their literary and artistic works'.

The author of this scientific research is convinced that the Article 2 gives the most exceptional and comprehensive information about the objects falling under Convention №1 and the way of how they shall be protected universally and in a particular country. For deeper understanding of the main focus of this article, particular quotations are given below:

'(1) The expression 'literary and artistic works' shall include every production in the literary, scientific and artistic domain, whatever may be the mode or form of its expression, such as books, pamphlets and other writings; lectures, addresses, sermons and other works of the same nature; dramatic or dramatico-musical works; choreographic works and entertainments in dumb show; musical compositions with or without words; cinematographic works to which are assimilated works expressed by a process analogous to cinematography; works of drawing, painting, architecture, sculpture, engraving and lithography; photographic works to which are assimilated works expressed by a process analogous to photography; works of applied art; illustrations, maps, plans, sketches and three-dimensional works relative to geography, topography, architecture or science.'

'(2) It shall, however, be a matter for legislation in the countries of the Union to prescribe that works in general or any specified categories of works shall not be protected unless they have been fixed in some material form.'

'(3) Translations, adaptations, arrangements of music and other alterations of a literary or artistic work shall be protected as original works without prejudice to the copyright in the original work.'

'(6) The works mentioned in this Article shall enjoy protection in all countries of the Union. This protection shall operate for the benefit of the author and his successors in title.
(7) Subject to the provisions of Article 7(4) of this Convention, it shall be a matter for legislation in the countries of the Union to determine the extent of the application of their laws to works of applied art and industrial designs and models, as well as the conditions under which such works, designs and models shall be protected. Works protected in the country of origin solely as designs and models shall be entitled (будут иметь право) in another country of the Union only to such special protection as is granted in that country to designs and models; however, if no such special protection is granted in that country, such works shall be protected as artistic works.'

Article I from the Appendix to this Convention mostly reflects the spirit of international sentiment at that time. It incorporates essential caveats regarding the developing countries and enables them 'gradual realization' of ensuring provisions related to protection of all the rights enshrined in the Convention.

Such a reservation is contained in paragraph (1) of Article 1 from the Appendix:

“ (1) Any country regarded as a developing country in conformity with the established practice of the General Assembly of the United Nations which ratifies or accedes to this Act, of which this Appendix forms an integral part, and which, having regard to its economic situation and its social or cultural needs, does not consider itself immediately in a position to make provision for the protection of all the rights as provided for in this Act, may, by a notification deposited with the Director General at the time of depositing its instrument of ratification or accession or, subject to Article $\mathrm{V}(1)(\mathrm{c})$, at any time thereafter, declare that it will avail itself of the faculty provided for in Article II, or of the faculty provided for in Article III, or of both of those faculties. It may, instead of availing itself of the faculty provided for in Article II, make a declaration according to Article V(1) (a). ${ }^{2} »$

\footnotetext{
2 Berne Convention for the Protection of Literary and Artistic Works of September 9, 1886, completed at PARIS on May 4, 1896, revised at BERLIN on November 13, 1908, completed at BERNE on March 20, 1914, and revised at ROME on June 2, 1928, at BRUSSELS on June 26, 1948, at STOCKHOLM on July 14, 1967, and at PARIS on July 24, 1971. https://global. oup.com/booksites/content/9780198259466/15550001
} 
To sum up all mentioned above, the author pays attention to the forethought and foresight of provisions of Convention 1, despite the fact of international copyright legislation had first started to form at that time.

Copyright naturally isn't a human right, but copyright protection in itself is considered as a tool which protects the human rights of authors and publishers. Notably, that copyright consists of two important elements that relate to human rights: 1) an element relating to someone's personal creativity and identity; 2) an economic aspect. As an author's right, copyright is not mentioned specifically in international human rights treaties and conventions. Instead, international treaties and national constitutions relates to it indirectly by giving creators and scientists the benefit of protection of "the moral and material interests resulting from any scientific, literary or artistic production of which he/she is the author."

Legal protection of moral and material interests of author is enshrined in Article 27 of the main international convention for the protection of fundamental human rights - The Universal Declaration of Human Rights, 1948 - the milestone document in the history of human rights. In this article is indicated the following:

«(1) Everyone has the right freely to participate in the cultural life of the community, to enjoy the arts and to share in scientific advancement and its benefits.

(2) Everyone has the right to the protection of the moral and material interests resulting from any scientific, literary or artistic production of which he is the author. ${ }^{3}$

The author proposes to review another one principal international convention protecting copyright - The Universal Copyright Convention (UCC), adopted in Geneva, Switzerland, in 1952, which complements the Berne Convention we have characterized earlier in this article. The UCC was designed by the United Nations

\footnotetext{
${ }^{3}$ United Nations. The Universal Declaration of Human Rights, 1948-1998. [New York]: [United Nations Dept. of Public Information], 1998. https://www.un.org/en/ udhrbook/pdf/udhr_booklet_en_web.pdf
}

Educational, Scientific and Cultural Organization (UNESCO) as an alternative to the Berne Convention for those countries that disagreed with provisions of the Berne Convention, but still wanted to participate in some form of international multilateral copyright protection. They included both developed and developing countries such as the United States and most of Latin America. The developing countries assumed that the strict copyright protections granted by the Berne Convention overly benefited Western, developed copyright-exporting nations; bearing in mind the US and Latin America were members of the Buenos Aires Convention by that time, a Pan-American copyright convention, that gives weaker protection of copyright than the Berne Convention.

The states have signed the Berne Convention also became party to the UCC, thus their copyrights would exist in non-Berne convention countries. In addition to these countries, the Soviet Union joined the UCC in 1973.

The United States legislation only provided copyright protection for a fixed renewable term, and it was required, in order for a work to be copyrighted, that it must contain a copyright notice and be registered at the Copyright Office. The Berne Convention, in contrast, provided for copyright protection for a single term based on the life of the author, and didn't require registration or the inclusion of a copyright notice for copyright to exist.

For that reason the US would have to make several substantial changes to their national copyright acts with the aim to become a party to the Berne Convention. In its turn, the UCC permits those countries that had a system of protection similar to the United States for fixed terms at the time of signature to retain them. In their turn, the USA determined to participate in the Berne Convention and changed its domestic copyright law as it required. In 1989 it has ratified the Berne Convention by enacting of the Berne Convention Implementation Act of 1988. To avoid the situation when countries, which initially ratified the Berne Convention, leave it and adopt the UCC instead, the UCC was amended by the "Appendix declaration relating to Article XVII' which implies: 
'(a) Works which, according to the Berne Convention, have as their country of origin a country which has withdrawn from the International Union created by the said Convention, after 1 January 1951, shall not be protected by the Universal Copyright Convention in the countries of the Berne Union;

(b) The Universal Copyright Convention shall not be applicable to the relationships among countries of the Berne Union insofar as it relates to the protection of works having as their country of origin, within the meaning of the Berne Convention, a country of the International Union created by the said Convention'4

Summarizing the foregoing, we can assert that The Universal Copyright Convention became the universal international document, which offered a system of copyright protection appropriate to all nations of the world, additional to, and without impairing international systems already in force, expressed in one paper.

The one more important detail is that almost all countries are either members or aspiring members of the World Trade Organization (WTO), and thus, comply with the Agreement on Trade-Related Aspects of Intellectual Property Rights Agreement (TRIPS), the UCC has lost significance when TRIPS came in force.

Therefore, the next international treaty we will analyze is the Agreement on TradeRelated Aspects of Intellectual Property Rights (TRIPS). It should be noticed, that it has been enacted as a result of The Uruguay Round negotiations lasted from 1986 to 1994.

In short, on 15 April, 1994, after long years of negotiations, Marrakesh declaration (protocol) to the General Agreement on Tariffs and Trade was succesfully signed, marking the establishment of the World Trade Organization (WTO). TRIPS has been negotiated at the end of the Uruguay Round of the General Agreement on Tariffs and Trade (GATT) between 1989 and 1990 and is administered by the WTO. Moreover, The TRIPS Agreement is An-

\footnotetext{
4 Universal Copyright Convention, with Appendix Declaration relating to Articles XVII and Resolution concerning Article XI 1952.

http://portal.unesco.org/en/ev.php-

URL I D $=15381 \& \mathrm{URL}_{-} \mathrm{DO}=\mathrm{DO}_{-} \mathrm{TOPIC}_{\mathrm{C}} \mathrm{URL}{ }_{-}$ SECTION $=201 . h t m l$
}

nex 1C of the Marrakesh Agreement Establishing the World Trade Organization, signed in Marrakesh, Morocco on 15 April, 1994.

In TRIPS minimum standarts for the regulation by national governments of most forms of intellectual property (IP) are set down, applicable to nationals of other WTO member nations.

Minimum standards for the regulation by national governments of many forms of intellectual property (IP), which are applicable to nationals of other WTO member nations, are set down in TRIPS ${ }^{5}$. There is a clause stupulated in Article 2 called 'Intellectual Property Conventions', which implies that current agreement does not affect the existing obligations, which its members may have to each other due to the Paris Convention, the Berne Convention, The Rome Convention and the Treaty on Intellectual Property in Respect of Integrated Circuits.

A fundamentally new norm was introduced by the Article 3 of TRIPS. It enshrined that each Member signed TRIPS shall accord to the nationals of other Members treatment no less favourable than it gives its own nationals concerning intellectual property protection, regarding the exceptions already provided in, respectively, the Paris Convention, the Berne Convention, The Rome Convention and the Treaty on Intellectual Property in Respect of Integrated Circuits.

The next innovation is stated in Article 9 which relates to the Berne Convention and implies the copyright protection status as follows: 'copyright protection shall extend to expressions and not to ideas, procedures, methods of operation or mathematical concepts as such'. Thus, the Agreement on Trade-Related Aspects of Intellectual Property Rights shall protect only expressions, not the ideas.

On December 20, 1996, Diplomatic Conference on Certain Copyright and Neighboring Rights Questions has taken place in Jeneva, which resulted in the adoption of World Intellectual Property Organization Copyright Trea-

\footnotetext{
5 AGREEMENT ON TRADE-RELATED ASPECTS OF INTELLECTUAL PROPERTY RIGHTS, Art. 1(3). https://www.wto.org/english/docs_e/legal_e/27trips_03_e.htm
} 


\section{Цивільне, підприсмницьке, господарське та трудове право}

ty. ${ }^{6}$ This enaction has been callep upon to make the international copyright protection system better. The coverage of this treaty as well as TRIPS Agreement extends to expressions, not the ideas, processes, methods of operation and mathematical conceptions per se. Refinement of existing international rules and establishing new ones are made in World Intellectual Property Organization Copyright Treaty.

During development and creation of provisions of this treaty the development of informational and communication technologies and their undeniable effect on creation and use of literary work and works of art were taken into account. Regarding that, the significance of this treaty is greatly increased.

This treaty is ad hoc agreement which has been developed due to the provisions of Article 20 of the Berne Convention. The computer programs, whatever the mode or form of their expression, have the same legal protection as literary works regardint it. Compilations of data or other material ("databases") that result from intellectual creativity, are also protected regarding WIPO Copyright Treaty. Thus, copyright protection does not extends to information or data per se, and also does not apply to the copyright, which connected data themselves or information, which containing in compilations.

WIPO Copyright Treaty grants authors of literary works and works of art the exceptional right to allow promulgation of their works by sale or transfer. Authors have an exclusive right of distribution of computer programs, cinematographic works and works of phonograms.

However, this right does not extend to computer programs, if a program isn't a main object of distribution, and cinematographic work, if such rent does not lead to broad copying of such works, which might undermine the exceptional right of reproduction.

Authors of literary works and works of art have the exceptional right to allow any kind of promulgation of their works by wire or wirelessly, includingly publicizing them in the way

\footnotetext{
${ }^{6}$ Ex. Rept. 105-25 - WIPO COPYRIGHT TREATY (WCT) (1996) AND WIPO PERFORMANCES AND PHONOGRAMS TREATY (WPPT) (1996). https:// www.congress.gov/congressional-report/105thcongress/executive-report/25/1
}

when public can undertake the access to such works anytime and anywhere, without breaking the provisions of Articles 11 (1) (ii), 11 bis (1) (i) and (ii), 11 ter (1) (ii), 14 (1) (ii) and 14 bis (1) of the Berne Convention.

The author summarizes that in addition to the Berne Convention, WIPO Copyright Treaty has enshrined internationally such new rights of author as: the right of allocation, right of distribution, right of promulgation.

In summary, the main conventions designed to protect copyright are reviewed in this article. All analyzed conventions, such as The Berne Convention for the Protection of Literary and Artistic Works, The Universal Copyright Convention (UCC), the Agreement on Trade-Related Aspects of Intellectual Property Rights (TRIPS), WIPO Copyright Treaty, are aimed at strengthening international copyright system and enshrining the minimum of copyright protection term, author's most fundamental rights and setting the provisions of gradual implementation of the same level of copyright protection for all signatory countries.

Thus, international community impacts on the formation of general principles on which the protection of human rights, as well as copyright, is builded. Countries which want to set relevant legislation to protect copyright, corresponding to requirements of time, should bring their legislation into line with these Conventions.

\section{ANALYSIS OF THE INTERNATIONAL LEGISLATION ON THE COPYRIGHT PROTECTION}

Artem Lisowyi - General specialist, the department of considering claims of citizens and providing of public information of the secretariat of the Civil cassation court as a part of Supreme Court

Human labour has always been sufficiently evaluated in developed countries across the world, it is precisely because of human work impacted the progress in the main spheres of human lives, such as economical, social, political and moral.

Significantly enough, that such an important and historically substantial thing as wheel is widely believed to have been invented by the ancient Mesopotamian people around 4200- 
4000 BC. It appears to have also been invented, independently in China, around 2800 BC. $^{7}$

Johannes Gutenberg, for example, invented the printing machine in 1450 , and in $19^{\text {th }}$ century iron components of such machine have been switched to wood details for speeding up the process of typing.

Another one example of how human labour impacts progress is the invention of James Watt, the Scottish inventor and chemist, who improved on Thomas Newcomen's steam engine with his Watt steam engine in 1776, which was fundamental to the changes brought by the Industrial Revolution in both his native Great Britain and the rest of the world. He also patented his invention in 1784 .

Thus, we should assert on that human ingenuity is the main engine of progress of the world and society. Without a human's creativity and will to develop conditions of living and work, there wouldn't be as large numbers of inventions as they are.

To date, the intellectual labour of people is under the protection of strict international legislation and it can't be otherwise if the world looks forward to the new inventions and improvements made by people. So, for obtaining of new developments and works of art, countries have to set strict and effective rules of law to their domestic legislation to protect copyright of people who have already invented new things and who are going to do such.

Owing to the foresight of countries' governments have been carrying and continue to carry about the juridical regulation of copyright in the international area and targeted work of international organizations such as WIPO, the European Union, countries may provide adequate degree for copyright protection for their citizens as well as copyrights are internationally protected at an appropriate level.

There is no doubt that when people know their rights are protected by the law, they have more potential and willing for creating new things. Accordingly, the strong protection of copyright gives a sense of care by a state for people, and thus they can feel comfortable when working on new inventions or works.

${ }^{7}$ D.T. Potts (2012). A Companion to the Archaeology of the Ancient Near East, p. 285.
The problem of establishment of international legislation on the copyright protection is that the majority of countries, as developed countries, have been working on development of their copyright legislation for years, thus they can provide the necessary protection of copyright for all works of art for everybody on their territories as it requires international conventions and treaties, and on the other hand, developing countries, so far they have a weak level of protection of human rights, not to speak of copyright protection. Therefore, the problem also concerns the necessity to establish strong rules of domestic law which are consistent with international copyright law.

The purpose of the article is to analyse the international legislation, such as conventions and international treaties, to define the legal protection and the legal regime for copyright. Such analysis will provide much more understanding of internationally established rules of law, intended for keeping property and nonproperty rights of author secure.

Also, this article will come in handy for people who have a lack of awareness on how copyright law functions. When they obtain and reflect on this information, they will eliminate legal nihilism and make a new way of relation to copyright. Thus, the number of copyright violations could be distinctly lower.

Among the scholars who investigate the issue of international rules of law, directed on the copyright protection, the following can be distinguished: Lionel Bently, Thomas Dreier, Jane Ginsburg, David Nimmer, Paul Goldstein, P. Bernt Hugenholtz, Goryan Yegor, Goryan Kristina, Krivolapov Bohdan and other.

Ukrainian scholars such as Kodinecz' Anatoli`j, Shtefan Anna, Grigor`yancz Galina, Khodaki`vs`kij Yevgen, Yakobchuk Valentina, Litvinchuk I’rina, Yakobchuk Valentina deserve special attention for their scientific contribution into the development of international copyright law.

Keywords: copyrights, copyright protection, The Universal Declaration of Human Rights, Berne Convention for the Protection of Literary and Artistic Works, World Intellectual Property Organization, establishment of copyright. 


\section{АНАЛІЗ МІЖНАРОДНОГО ЗАКОНОДАВСТВА ПРО ЗАХИСТ АВТОРСЬКИХ ПРАВ}

Аісовий Артем - головний спечіаліст відділу розгляду претензій громадян та надання публічної інбормачиї секретаріату цивільного касаційного суду у складі Верховного Суду (Київ,

украӥна)

ᄉюдська праця завжди високо цінувалась у розвинених країнах по всьому світу саме тому, що вона впливає на розвиток головних сфер людського життя, такі як економічна, соціальна, політична та духовна.

Видатним є те, що така важлива та історично значуща річ, як колесо, за дуже розповсюдженою думкою вважається винайденою стародавніми месопотамцями у близько 4200-4000 роках до нашої ери. Також існує думка, що воно було винайдено незалежно у Китаї, десь у 2800 році до нашої ери.

Йоганн Гутенберг, наприклад, винайшов друкарську машину у 1450 році, а у 19 столітті металеві складові цієї машини змінили на дерев’яні для прискорення процесу друкування.

Ще одним прикладом того, як людська праця впливає на науково-технічний розвиток, є винахід Джеймса Ватта, шотландського винахідника та хіміка, який вдосконалив паровий двигун Томаса Ньюкомена, побудувавши власний - паровий двигун Джеймса Ватта у 1776 році. Він став фундаментальною зміною серед привнесених Промисловою революцією, як для його рідної Великобританіїі, так і для решти світу. Він також запатентував свій винахід у 1784 році.

Як наслідок, ми можемо наполягати на тому, що людська винахідливість - це головна рушійна сила розвитку світу та суспільства. Без людської креативності та бажання удосконалювати умови життя та праці не було б такої великої кількості винаходів, як 6 .

На сьогодні нтелектуальна праця людей знаходиться під захистом жорсткого міжнародного законодавства, і не може бути інакше, якщо світ розраховує на нові людські винаходи та вдосконалення, зро- блені людьми. Так, для отримання нових розробок та творів, країни мають встановити суворі та ефективні юридичні норми у своєму національному законодавстві, для захисту авторських прав творців.

Завдяки далекоглядності урядів країн, які давно займаються розвитком та продовжують розвивати правове регулювання авторських прав у міжнародному простоpi, та цілеспрямованій роботі міжнародних організацій, таких як Всесвітня організація інтелектуальної власності (ВОIВ) та Європейський Союз, велика кількість країн може надавати належний рівень захисту авторських прав для своїх громадян, а на міжнародному рівні авторські права також захищені на належному рівні.

Немає сумнівів, що коли люди усвідомлюють, що їхні права захищені на законодавчому рівні, вони мають більший потенціал та бажання для створення нових речей. Зважаючи на це, потужний захист авторського права дає людям відчуття захисту зі сторони держави, а тому вони можуть почувати себе надійніше, працюючи над новими винаходами або творами.

Проблема становлення міжнародного законодавства у сфері авторсъкого права полягає в тому, що більшість розвинених країн працювала над розвитком їх місцевого законодавства у сфері авторського права протягом довгого часу, а значить, може надавати необхідний захист авторських прав усім роботам та творам мистецтва на своїй території, як того потребують міжнародні конвенції та договори, але 3 іншого боку країни, що розвиваються, які не займалися питанням захисту прав людини, а тому мають незадовільний рівень їх захисту, не кажучи вже про забезпечення захисту авторського права. У свою чергу, зазначена проблема також стосується необхідності встановлення суворих правил у місцевому законодавства країн, які будуть узгоджені із нормами міжнародного права.

Мета cmammi полягає у тому, щоб проаналізувати чинне міжнародне законодавство, таке як конвенції та міжнародні договори для визначення юридичного захисту та правового режиму авторських прав. Такий аналіз дасть змогу набагато більшого розу- 
міння встановлених міжнародних норм права, що покликані охороняти майнові та немайнові права автора.

Також ия стаття стане доречною для mux, хто має брак розуміння того як авторські права функціонують. Після отримання та осмислення викладеної інформації вони викорінять власний правовий нігілізм та зможуть виробити новий підхід у розумінні авторських прав. I таким чином, кількість порушень авторського права може стати набагато менша.

Серед науковиів, які досліджували питання міжнародних норм права, які регулюють захист авторського права, можна виділити наступних: Аіонель Бентлі, Томас Драйєр, Джейн Гінсбург, Девід Німмер, Пол Голдштейн, П. Бернт Гугенхольц,
Єгор Горян, Крістіна Горян, Богдан Криволапов та інші.

Такі українські вчені, як Анатолій Кодинець, Анна Штефан, Галина Грігор'янц, Евген Ходаківський, Костянтин Зеров, Ірина Літвінчук, Валентина Якобчук, Сергій Петренко, заслуговують на спеціальну увагу за свої наукові доробки у сфері дослідження розвитку міжнародного авторського права.

Ключові слова: авторське право, захист авторського права, Загальна декларація прав людини, Бернська конвенція про охорону літературних і художніх творів, Всесвітня організація інтелектуальної власності, становлення захисту авторського права 